\title{
GENDER-FAIR LANGUAGE IN A MINORITY SETTING: THE CASE OF BRETON $^{1}$
}

\author{
MICHAEL HORNSBY
}

Adam Mickiewicz University, Poznań

\begin{abstract}
This paper explores the use of the Breton language (Brittany, North-West France) in contexts where speakers wish to signal their commitment to social equality through their linguistic practices. This is done with reference to examples of job advertisements which have pioneered the use of gender-fair language in Breton. Linguistic minorities are often portrayed as clinging to the past. This paper, however, sheds a different light on current minority language practices and demonstrates a progressive and egalitarian response to modernity among some current speakers of Breton, in their attempts to assume gender-fair stances.
\end{abstract}

Key words: Breton, minority language, gender-fair language, new speakers

\section{Introduction}

In this article, we examine first how linguistic minorities in France are somehow rendered invisible, or 'erased' (referring to Irving and Gal's (2000) work on erasure) and then extend this sense of erasure to challenge the frequent imagined homogenization of minority groups, in which marginalized populations within identified minority groups are further erased. In Brittany,

1 The author would like to warmly thank Drs Julie Abbou (Aix-Marseille University), Joanna Chojnicka (Adam Mickiewicz University, Poznań) and Karolina Rosiak (Adam Mickiewicz University, Poznań) for their reader comments on the present article.

(c) Copyright by The Faculty of English, Adam Mickiewicz University 
this has begun to be challenged through the emerging use of 'gender-fair language' to reflect the presence of people other than men in public and institutional life. The Breton-language community is located almost exclusively within the Francophone sphere of influence, and as a result, there are clear indications, examined in this article, of how wider societal recognition of gender equality is beginning to be reflected at a more micro, local level within minority languages in France, particularly (as is our focus here) in Brittany. The mechanisms for reflecting gender equality in Breton are examined in particular in the case of job advertisements written in Breton and which try to adhere to wider, French norms of inclusive language. Since Breton, as a Celtic language, is morphologically and syntactically distinct from French, attempts to make it more inclusive can be classified as sociological and cultural phenomena, rather than purely linguistic, as a brief comparison with a related Celtic language, Welsh, attempts to demonstrate. The article concludes with locating this trend within a particular delimitable social and professional sphere.

\subsection{Breton speakers, invisible speakers}

The overall lack of visibility for Breton speakers in general is first due to the absolute numbers of speakers, which are now quite low (Broudic 2009). The total number of speakers was estimated at just over one million people around 1950. Since the end of the Second World War, Breton has lost $85 \%$ of its speakers over 60 years (Broudic 2009). According to the TMO Regions Institute Survey (2007, in Broudic 2009), 172,000 Breton speakers (90\%) resided in Western Brittany, a drop of $30 \%$ in the total number over ten years since the estimate of 1999. In 2007, only 35,000 speakers reported using Breton on a daily basis. Broudic (2009) estimates there are only 12,000 speakers of Breton in the 25-50 years age group. The social spaces associated with the practice of Breton are becoming more and more restricted as a result. Even though in 2018 the Regional Council published an updated estimate of over 200,000 Breton speakers (which represents a higher number than previously estimated), uncertainty in the exact number of speakers does not mitigate the fact that overall we are witnessing a fast decrease in the absolute number of speakers of the language. Ó hIfearnain sums up the situation accurately when he states that 'intergenerational transmission of Breton has been declining very rapidly in each generation, especially in the last 50 years' (Ó hIfearnáin 2011: 97).

The Breton language still lacks societal visibility apart from its increasing (symbolic) presence in the linguistic landscape. Breton speakers are not detectable when they speak French, as they show the same local accents as French monolinguals. Secondly, when Breton speakers do use the language, this is mostly out of the earshot (or sight) of monolingual French speakers. 
Periodicals and magazines in Breton are not on general display in kiosks and bookshops, since they are in the main only available by subscription. On the television, the public service broadcasts only 70 hours of programmes in Breton per year, and four radios broadcast partially or exclusively in Breton in their respective regionally-based territories. The internet provides more of a Bretonlanguage presence, on social media and on the web-TV Brezhoweb. Job advertisements in Breton can be found on the website of the Ofis Publik ar Brezhoneg ('Office of the Breton Language') or the website Ubapar (see Section 2.2 for examples of these). In 2007, the Office of the Breton Language created the "spilhennig", a badge for Breton speakers to wear on their clothes in order to recognize each other in public, similarly to the use of the Fáinne in Ireland, or the iaith gwaith pin or lanyard in Wales. However, the logo is not self-explanatory and means nothing to non-Breton speakers (Jouitteau 2019: 15-16).

Moreover, for minority languages in general, there is a lack of recognition of speaker diversity within the speech community, as has been pointed out in the Council of Europe (2010) publication, 'Mosaic: The training kit for EuroMediterranean youth work':

Despite the recognition of cultural diversity as a natural phenomenon and the
existence of different declarations to ensure the protection of cultural diversity,
much remains to be done to protect the rights of minorities. Part of the problem
lies in addressing minorities as homogeneous entities rather than recognizing
the internal diversities within them. One suggestion is that the static recognition
of cultural diversity should be broadened and replaced by a commitment to the
opportunity for equal and full participation of all people with no exception.
(Council of Europe 2010: 180, emphasis added)

Very often, a simplistic division is offered for Breton, mainly based on age and gender. The typical profile of a person who speaks Breton has been described as a woman over 60 living in Penn-ar-Bed (Finistère) (Broudic, 2009). With the very low levels of intergenerational transmission reported above, and with the top heavy, age-wise, demographics of Breton speakers (meaning that year in, year out, the older speakers are becoming fewer in number: Broudic (2009) has shown that the number of Breton speakers decreased by $28 \%$ between 1997 and 2007, for example), hope seems to rest on the reproduction of the Breton speaking community through the appearance of new speakers (néo-bretonnants, brezhonegerien nevez), who might represent a younger, more consciously engaged type of speaker. As the former mayor of Quimper, Bernard Poignant, has said: "[le breton] a cessé d'être une langue maternelle, à part quelques rares cas. A partir de là, elle ne peut perdurer que par la volonté militante" ("the Breton language has ceased to be a first language, apart from a few rare cases. From that point, it cannot continue unless it's connected to an activist commitment") (Raynaudon-Kerzerho et al. 2010: 54). 


\subsection{New speakers of Breton}

We now turn to an emerging field of investigation in minority language sociolinguistics, the 'new speaker'. The new speaker paradigm allows an exploration of gender-fair language on two levels. First, the lack of intergenerational transmission highlighted above implies that many politically engaged, younger speakers will be new speakers of Breton (see below for a discussion of the term, 'new speaker'). The world of Breton activism is linked and intersected via language, politics, social issues, etc, and as became clear through the examination of the data discussed below, a broadly left-wing approach to gender-fair language was discernible. Thus the stance of a new speaker of Breton can be (though not always, or consistently, of course) tied in with broader social issues which seek to redress injustices and inbalances, of which feminism will be one important strand. Secondly, O'Rourke and Pujolar (2019: 7) have linked the current recognition of new speakers with a broader "need for specific social spaces to be created so as to provide access to different types of speakers" The opening up of a wider diversity of speaker spaces allows for otherwise marginalized speakers to find a voice, once of which seeks to make some spaces, at some times, more gender-neutral or more gender-fair, as is discussed in the sections which follow.

The term 'new speaker' most often refers to regular users of a language but who were not raised with that language as their primary language of socialisation in the early years. The concept of new speaker is based on a critique of linguistic categories which a number of researchers have deemed insufficient in describing people who adopt multilingual repertoires in their daily lives, such as: 'L2 speaker', 'non-native speaker', 'learner' etc. (O'Rourke et al. 2015). Other sub-disciplines of linguistics had problematized these categories since the 1970s (cf. Davies 2003), but without actually using the term 'new speaker'; this has come to be now associated most often with minority languages. The new speaker description has been used to describe language users with a wide range of language competences, which range along a continuum from emergent speakers (see García and Kleifgen 2010) - or speakers with limited linguistic repertoires - through to expert speakers (Rampton 1990) who often can pass as a native speaker (Piller 2001). Most recently, O'Rourke \& Pujolar (2019) have shown how the new speaker paradigm, more widely subsumed in what they consider "a sociolinguistics of the speaker", allows researchers "to illuminate who has access to which codes, how and where they are able to deploy them, and with what social and economic consequences, across a wide range of settings in today's multilingual, globalised Europe" (O'Rourke \& Pujolar 2019: 27). In other words, by challenging traditional paradigms with new concepts (such as new speakers), 
exploring power differentials and differences in access to various codes allows us to explore new linguistic practices, which otherwise might be lost in more traditional and conservative sociolinguistic investigations.

Many habitual or daily speakers of minority languages are now emerging in quite different ways than was previously the case. As new speakers become more and more common in many minority communities, tensions can occur over what their role is in language revitalization. Moreover, given that many young new speakers gain their 'speakerhood' through bilingual or immersion programmes or other formal instruction, their linguistic practices (especially accent) may be perceived as aberrant or somehow inauthentic. Of course, other new speakers may come from more traditional backgrounds, with speakers of the minority language within their immediate or extended family, or in their local community and these speakers may represent the outcome of complex mixed model of revivalist and maintenance strategies in particular revitalization settings (Hornsby 2015: 3).

The main criterion, I would argue, for defining a speaker as 'new' or as 'traditional' lies not so much in the speaker's proficiency (since a proficient speaker can arrive at such a position from a variety of starting points), but more a sense of belonging (or not) to and a recognition/acknowledgement on the part of the minority language community in question. For new speakers, then, to be 'new' is to be an 'unexpected' speaker, as Smith-Christmas et al. have sought to explain: "At its most basic level, the designation 'new speaker' refers to social actors who use and claim ownership of a language that is not, for whatever reason, typically perceived as belonging to them, or to "people like them" (Smith-Christmas et al. 2018: 4). This unexpected aspect occurs, according to Ó Murchadha and Ó hIfearnáin, "because new speakers tend to transgress the sociocultural profiles of an imagined ideal speaker and because they also, and not infrequently, move beyond what is regarded as authentic, legitimate, and correct language usage" (Ó Murchadha and Ó hIfearnáin 2018).

\section{Making the invisible visible}

One of the ways a minority of Breton speakers are currently signalling diversity among their ranks is through evolving linguistic practices, where non-canonical ${ }^{2}$ speaker status can be marked through particular linguistic forms. Here, I am particularly interested in how certain speakers of Breton, in certain contexts, are working to establish diverse and varied linguistic practices to signal their

2 By this, I mean anyone who does not fit Broudic's (2009) profile of a Breton speaker as an elderly woman living in the countryside. 
existence within the Breton-speaking world. In particular, the focus in this paper is on the use of so-called feminized language to problematize gender differentiation as a dominant discourse (Baxter 2005). We begin by looking at the mechanisms of how gender-fair language in French is achieved and then proceed to see how this is mirrored, but to a lesser extent, in a Breton context. While French and Breton are typologically different, they do share the same social, cultural, geographical and - above all - the same political spaces, and so a thorough understanding of how these mechanisms are entering Breton through a French-language filter is necessary.

\subsection{Background in France}

Breton speakers, with some notable exceptions, exist within la Francophonie, or the French-speaking world. Within this globalized speech community, in much the same way as other globalized speech communities, certain attitudes towards language, and particular language ideologies circulate in specific ways which may not be directly reflected in other transnational language spheres. At this juncture, it makes sense to examine the evolution of gender-fair language practices in France, and the mechanisms for doing so, since these practices directly influence Breton-language approaches, as I show below.

More widely, in the French-speaking world, there has been a number of attempts to mark gender diversity in language in the 1970s, 1980s, and through the 1990s. Quebec, for example pioneered linguistic reform by making job-title feminization official in 1979. French-speaking Switzerland adopted feminization in 1990, and la Communauté française de Belgique published, in 1994, its official guide to the feminization of job titles. This trend was less popular in France during this period, however, and while arguments for and against linguistic feminization in France were discernible in the mid-1980s, actual linguistic practices were not really in evidence until 1997, when several female members of Assemblée nationale demanded the title Madame la ministre 'Madame minister' (Burnett \& Bonami 2019). This resurgence of profeminization arguments led then-Prime Minister Lionel Jospin to charge la Commission Générale de terminologie et de néologie with re-examining jobtitle feminization in 1998. The Commission delivered its report later that year, declaring that there was no obstacle in principle to grammatical feminization ..." (Van Compernolle 2009: 35). Such moves are opposed by the French-language regulatory body, the Académie because they are considered 'damaging', indicating that the issue is definitely ideologically-based rather than linguistic (Van Compernolle 2009: 36). 
2.2. Mechanisms for producing gender-fair language in French

Table 1: Mechanisms for creating gender-fair language in French (based on Abbou 2011: 60-70)

\begin{tabular}{|c|c|c|}
\hline $\begin{array}{l}\text { Mechanism for creating } \\
\text { gender-fair language }\end{array}$ & Examples & Comment \\
\hline \multicolumn{3}{|l|}{ Typographic level } \\
\hline Dash & familiè-r-e-s & 'RAD-familiar[= fem]-[+pl.]' \\
\hline Slash & traducteurs/trices & 'RAD-translators[+masc pl.]/[+fem pl.]' \\
\hline Upper case letters & mauvaisES & $\begin{array}{l}\text { 'RAD-bad }[=\text { masc (lower case) }][+ \text { fem (upper } \\
\text { case) }[+ \text { pl. (upper case) }] '\end{array}$ \\
\hline Underlining & sauvages & 'RAD-wild[end of radical/fem] [pl. mark]' \\
\hline Amalgamations & ille & 'she/he[= mix of masc il \& fem elle $] '$ \\
\hline \multicolumn{3}{|l|}{ Morphosyntactic level } \\
\hline The use of doublets & $\begin{array}{l}\text { les travailleurs, } \\
\text { les travailleuses }\end{array}$ & 'the workers [masc], the workers [fem]' \\
\hline Alternative forms & $\begin{array}{l}\text { captifVEs / } \\
\text { radicales-aux }\end{array}$ & $\begin{array}{c}\text { 'RAD-captive[+ masc (lower case) [+ fem (upper } \\
\text { case)] [+pl. (lower case)]' (masc form first) / } \\
\text { 'RAD-radical[+ fem pl.]-[+masc pl.]' (fem form } \\
\text { first) }\end{array}$ \\
\hline Epicenes and hypernyms ${ }^{3}$ & individuE & $\begin{array}{l}\text { 'InvariableRAD-individual[=masc (lower case) }] \\
{[+ \text { fem (upper case)]' }}\end{array}$ \\
\hline Morphological innovations & voleurE & $\begin{array}{l}\text { 'RAD-robber[= masc (lower case)] [+fem (upper } \\
\text { case)]' (stand. voleur/voleuse) }\end{array}$ \\
\hline Non-marked items & - & $\begin{array}{l}\text { Single gender marking is used when the writer } \\
\text { wishes to critique gender categories }\end{array}$ \\
\hline \multicolumn{3}{|l|}{ Lexical level } \\
\hline Neologisms & ceulles / celleux & $\begin{array}{l}\text { Contractive forms of celles et ceux 'those }[=\text { fem }] \\
\text { and those[=masc]' }\end{array}$ \\
\hline
\end{tabular}

The above table is by no means exhaustive, and since the publication of the article by Abbou in 2011, other techniques have been noted. Robiche (2018) has remarked on the following in particular:

3 A hypernym has a fixed grammatical gender (l'individu 'the individual' [masc]) but can refer to either gender, whereas an epicene can be accorded either gender (le/la pilote 'the [masc/fem] pilot') (Abbou 2011: 38). 
- The use of brackets: les étudiant(e)s 'RAD-students[=masc]+[(fem marker in brackets)]

- Suspended full stop: les chanteur $\bullet$ se $\bullet$ 'RAD-singer•(fem suffix) $($ pl. suffix)'. According to Robiche, this technique is 'preferable' to the full stop technique mentioned above because it stops automatic readers from assuming a dot on the line is the end of a sentence (Robiche 2018: 42).

- Replacing a letter which refers to gender with a neutral symbol: $t u l^{*}$ vois 'You see him/her [* replaces e (masc) or a (fem)]'; m_partenaire: 'my [_replaces -on (masc) or - $a$ (fem)] partner'

- Using the feminine form as the generic: toutes les auditrices 'all the members (fem) of the audience'

- Reformulation to make the reference less gender specific: supervision professorale 'professorial supervision' instead of supervision par le professeur 'supervision by the professor (masc)'

- Mixing masculine and feminine nouns and adjectives: certains militantes 'certain (masc) activists (fem)' (Robiche 2018: 40-42)

It can thus be seen that gender-fair or inclusive terms in French employs a wide range of mechanisms and techniques in order to achieve its aim of more equal representation in language. Certain writers can use all or just some of these techniques, and there appears to be a good deal of personal variation and/or preference in the choices made, which Toussaint and Krazem (2017: 4) trace back to 'enunciative, social and even ideological and psychological factors' (my translation). They do, however, identify .e as being the marker of so called 'feminized' language, since it is the most stabilized variant and in many ways has come to represent inclusive language tout court (Toussaint and Krazem 2017: 2)

\section{Gender-fair language in French}

In Brittany, making language gender-fair presents different grammatical considerations from French and these need to be taken into account. The Breton language is 'marked' in different ways to French as far as gender is concerned for example, adjectives have less variability than their French counterparts, and are not marked for gender or number through the addition of suffixes. Nouns can be marked for gender, through the addition of feminine suffixes and also through the use of initial consonant mutation. For example, kelenner ('teacher'): ar c'helenner ('the teacher', m.) but ar gelennerez (the teacher, f.). Associated adjectives are marked through the same technique of word-initial mutation (but not through the addition of suffixes, unlike in French): ar c'helenner mat ('the 
good teacher', m.) but ar gelennerez vat ('the good teacher', f.). These, and a number of other grammatical considerations, need to be taken into account when making language gender-fair in Breton.

In the French-speaking world, then, the influence of linguistic egalitarian practices in French are filtering through to Breton, since language trends in the majority language seem to be appearing in the minority language in roughly the same way. Moreover, according to one person I interviewed during fieldwork in Brittany in November 2018, there is now an explicit expectation among language planners in Brittany (such as Ofis Publik ar Brezhoneg, a public institution with state and regional cooperation and funding which promotes and develops teaching and use of the Breton language in daily life) that this will become the norm, following French-language practices (Bramoullé, private communication, 21/11/18).

It is becoming increasingly the case that job advertisements in Frenchspeaking countries employ inclusive language. Lipovsky (2014), for example, found that in her study of 368 advertisements from three French newspapers, analyzed in May 2012, at least one third of them was gender-inclusive, using either an epicene (= identical feminine and masculine forms) occupational noun and gender-inclusive text, or a feminine and masculine occupational noun and gender-inclusive text or, less frequently the advertisement focuses on the task rather than the person (Lipovsky 2014: 375). Similar practices appear to be emerging in the Breton-speaking press as well. In extract (1) below, the root word for teacher, kelenner, has the feminine suffix (-ez) attached with a dot. The same can be seen in extract (2), a job advertisement for a teaching assistant. The word for teaching assistant is 'skoallezer mamm' (based on Fr. assistant maternel) in the masculine. To make it gender-fair, not only does the feminine ending -ez have to added (skoallezerez), the subsequent adjective mamm has to undergo initial consonant lenition to mark it as feminine as well (mamm > vamm). We thus arrive at skoazeller.ez-m.vamm to signal that the position is open to both female and male candidates.

(1) Advertisement for a job teaching through the medium of Breton (Source: Marc'had al Labour, Ofis Publik ar Brezhoneg: http://www.brezhoneg.bzh/73marchad-al-labour.htm, accessed 1 November 2018)

\section{ORIGINAL}

KELENNER.EZ ER 1AÑ DEREZ

KATOLIK

Lec'h: [redacted]

Tachenn: Kelenn e brezhoneg

Deiziad: 30/11/2018

\section{TRANSLATION}

TEACHER IN THE CATHOLIC

PRIMARY SCHOOL SYSTEM

Location: [redacted]

Position: Breton-medium instruction

Date: 30/11/2018 
Doare: Darnamzer (Kevret termenet Contract: Part-time (pro-rata) he fad)

Post da bourvezañ d'an: Diouzhtu Position to start on: Immediately

(2) Advertisement for a job as a Breton-speaking nursery school assistant (Source: Marc'had al Labour, Ofis Publik ar Brezhoneg: http://www.brezhoneg.bzh/73-marchad-al-labour.htm, accessed 1 November 2018)

\section{ORIGINAL}

SKOAZELLER.EZ-M.VAMM

Lec'h: [redacted]

Tachenn: Buhezañ er skol Position:

Deiziad: 30/11/2018

Doare: Darnamzer (Kevret termenet he fad)

Post da bourvezañ d'an: Diouzhtu

\section{TRANSLATION \\ NURSERY ASSISTANT}

Location: [redacted]

Leading activities in the school

Date: 30/11/2018

Contract: Part-time (pro-rata)

There appears to be an evolution in the typographical conventions to show equality of opportunity in more recent job advertisements. A more recent advertisement ${ }^{4}$ (September 2019) for a teacher of humanities in the Diwan immersion school network demonstrated the use of the raised dot before the feminine ending -ez: Kelennerez war an Istor-Geografiezh. This fits in with Robiche's observation above that this practice is seen as increasingly preferable because it is in fact the most fully inclusive, allowing automatic readers not to mistake it for a full stop instead (Robiche 2018: 42).

Other examples of job advertisements in Breton show greater complexity in gender-fair techniques. For example:

(3) Emañ K.L.T. (Kerne-Leon-Treger) o klask ur g/c'helenner.ez brezhoneg evit an dud deuet ('KLT [teaching organisation] is looking for a teacher of Breton for adults')

(4) Klasket e vez ur c'helenner (ez) war an istor-douaroniez $h^{6}$ ('A teacher is being sought to teach History/Geography')

\footnotetext{
4 https://www.diwan.bzh/br/offres-emplois/kelenner-ez-war-an-istor-geografiezh250920190923 (accessed 22 March 2020)

5 https://www.roudour.bzh/Poste/kelenner-brezhoneg-dan-dud-deuet-ha-tanva-er-skoliou/ (accessed 15 August 2019)

6 https://www.facebook.com/stumdi/posts/klasket-e-vez-ur-chelenner-ez-war-an-istordouaroniezh-post-er-skolaj-sant-josef/556778377839709/ (accessed 15 August 2019)
} 
In both cases, the use of the indefinite article $u r$ causes a mutation of the initial letter of kelenner 'teacher': c'h as a masculine marker and $g$ as a feminine marker. Note that extract (3) provides a full gender-fair form through the use of a slash (ur g/c helenner.ez) plus the feminine agent suffix $-e z$, whereas the radical form in (2) is just marked as masculine, with the feminine suffix added in brackets (almost as an after-thought).

If we compare the situation in Wales (extract 5), on the other hand, because it is in the Anglosphere, this issue is handled in a fairly different way. Welsh is closely related to Breton, and has similar ways of marking the feminine, much in the same way Breton does (though the system is slightly less complex). English does not mark the feminine as much as in French, Breton, or indeed in Welsh, so users of the Welsh language who wish to use egalitarian language tend to use the doublet technique, but note it is only done in the case of 'teacher' (Athro/Athrawes). All other animate nouns in the extract are left in their masculine forms (llywodraethwyr 'governors'; ymgeisydd/ymgeiswyr 'candidate/candidates', even though feminine forms are available [llywodraethwragedd; ymgeisyddes/ymgeisyddesau], according to Geiriadur Prifysgol Cymru/The University of Wales Dictionary).

(5) Advertisement for a job as a teacher in a Welsh-medium primary school (Source: eTeach International: http://www.eteach.com, accessed 1 November 2018)

\section{ORIGINAL}

32.5 awr, Cyfnod penodol tan $19 / 07 / 19$

Athro / Athrawes llawn amser ar gyfer Tymor yr Haf 2019 yn unig.

Hoffai Llywodraethwyr Ysgol [redacted] benodi athro / athrawes ddosbarth sydd yn gymwys ar gyfer dysgu ar draws yr ysgol.

Bydd yr ymgeisydd llwyddiannus yn gweithio fel rhan o dîm ymrwymed ig yr ysgol sydd yn gosod safonau a gofynion uchel. Mae'r gallu i siarad Cymraeg yn hanfodol.

Gofynnwn i'r ymgeiswyr ein hysbysu am fedrau cwricwwlaidd.

Mae croeso i ymgeiswyr ddod i ymweld â'r ysgol neu i drafod y

\section{TRANSLATION}

32.5 hours, specific period until 19/07/2019

Full-time teacher for the Summer Term 2019 only.

The governors of Ysgol [redacted] would like to appoint a class teacher who is able to teach across the school.

The successful candidate will be working as part of a committed school team which sets high standards and expectations. The ability to speak Welsh is essential.

We request that the candidates inform us of their curricular skills.

Candidates are welcome to come and visit the school or to discuss the 
swydd gyda'r pennaeth dros dro position with the temporary [redacted] headteacher [redacted]

Languages can thus be used in ways that promote gender equality (Sczesny, Formanowicz and Moser, 2016) to different degrees. And it has been found that linguistic structure can be related to societal gender equality: in a study by Prewitt-Freilino et al. (2012) countries with grammatical gender languages reached lower levels of general gender equality than countries with natural gender languages and genderless languages.

\section{Discussion}

Some of the earliest feminist work on gender and language sought to demonstrate that gender-specific language practices and sexist language result from and reflect existing social inequalities and contribute to the maintenance of such inequalities (Lakoff 1975; Zimmerman and West 1975; Fishman 1978; Spender 1980; Maltz and Borker 1982). As women's progress toward equal opportunity and participation has picked up in the job market, not least in France as elsewhere, the appearance of gender-fair language in job advertisements is an attempt to counteract the invisibility of women in language and in the workforce in spite of their ever-increasing participation (Pauwels 1998).

In minority language settings, particularly within the context of the French state, women can be subjected to double invisibility. All speakers of a minority language in France can be erased through the lack of recognition of the minority language itself; as Hawkey (2018) reminds us:

Institutional support from the French government for RMLs [regional minority languages] is still nearly non-existent ... Article 1 indicates that France is an 'indivisible Republic', and article 3 specifies that 'national sovereignty belongs to the people' and that this sovereignty 'may not be exercised by any one individual or section of the people' (République Française 2015). As such, collective rights are anathema to the indivisibility of French Republican sovereignty, and this is frequently used as a reason to not accord specific rights to minority groups (of all persuasions, not just RML communities)

(Hawkey 2018: 191, 195)

In addition, as noted above regarding the lack of recognition of speaker diversity in minority language communities, much in line with Irvine and Gal's (2000) identification of 'erasure' (p. 37) as one of the 'semiotic processes' by which 'a social group or a language may be imagined as homogeneous, its internal variation disregarded' (p. 38), and which 'renders some persons or 
activities (or sociolinguistic phenomena) invisible' (p. 38), means women as speakers can be erased as equal members of a minority language community. Suggesting that minorities can contain their own minoritized members is contentious, of course, but with the appearance of gender-fair language in a small number of Breton-language job advertisements would seem to indicate that some members of the community have recognized the unequal treatment of women in their midst in the past and that they are attempting to now address this inequality.

Moreover, the use of gender-fair language in France has been identified as occupying a particular niche, a 'delimitable social sphere. The university, trade union or political environment tends to dominate' (Toussaint and Krazem 2017: 4, my translation). We can take note of the fact that the above job advertisements are drawn from the educational sphere in Brittany, and have been taken from broadly left-wing, activist websites. Advertisements for jobs in the private, associative immersion school network, Diwan, for example, seem to reflect this left-wing approach to equal opportunities. In fact, this association of the network with a progressive political stance has been already noted in the literature. Former Diwan students have been indentified as a group with distinct characteristics, such as having left-wing and ecological values (Kernalegenn, 2006). Elsewhere, I have noted that some Diwan high school pupils have expressed antipathy towards modernist, consumerist values (Hornsby 2019: 398).

The use of inclusive language in Breton can be linked to the increased presence of 'new speakers' of the language. These new speakers, some of whom will have no family connection with the language prior to becoming speakers themselves, inject a new level of difference into Breton-speaking milieux, and can bring issues of diversity and equality to the fore. The case should not be over-stated, of course, and differences of opinion towards political issues such as gender equality will be found among the speaker population, whatever the origin of the individual speaker. It is clear, however, that the presence of a more diverse population, achieved through individual linguistic trajectories towards becoming a Breton speaker, means that awareness of the heterogeneity of the Breton-speaking world is much higher than it might otherwise have been, had intergenerational transmission of the language been more prevalent over the course of the $20^{\text {th }}$ century.

The examples taken from job advertisements in Breton all demonstrate that gender-fair language in Breton is overwhelmingly at the typographical level. No examples were found of the morphosyntactic or the neologism levels identified by Abbou (2011) for French. In this way, we might note that .ez could be in the process of becoming the equivalent of the.$e$ marker in French, indexing not just inclusive language, but also a much broader political and social stance on the 
part of the writers of the job advertisements and consequently of the institutions and associations these job advertisements represent.

\section{Conclusion}

This overview provides the first investigation (to the best of my knowledge) of sociolinguistic issues involving an analysis of the discourses used to promote gender-fair language in Breton, or in any other Celtic language, for that matter. Having asked colleagues in Wales if there are aware of any similar research in Welsh, I have been told that there was a passing mention of inclusive language in Welsh in a report in the 1990s, but that nothing of substance has been published. Despite being a Celtic language typologically speaking, the move to make the Breton language more gender-fair arises out of a contact situation with French, where this process is much more advanced than in English (the contact language for the other Celtic languages). In this particular instance, it is more appropriate to investigate the situation of Breton through the lens of the sprachbund or area of sociolinguistic diffusion given that gender-fair language in Welsh, for example, appears to be less accepted or not particularly an issue. Moreoever, more research needs to be done on the intersection between the 'minority condition' from multiple stances. As indicated earlier, the tendency to treat linguistic minorities as homogenous blocks fails to unpick the real picture, since speakers of a minority language are as varied and diverse as any majority language group of speakers. One very small recognition of how feminism (to take one example) can intersect with minority language planning was reported The Atlantic in 2017, where it was noted that, '[t] he French Association of Normalization, which coordinates the standards-development process among French businesses, announced that it is designing a new keyboard that will include the median-period. The move will please not only the proponents of inclusive writing, but also the speakers of minority languages in France (like Catalan, Occitan, and Gascon), who have always used the median-period as a phonetic marker' (Timsit. The Atlantic, 24.11.2017, italics mine). Such links need to be explored more fully through the lens of intersectionality if we are to gain a much more accurate picture of what it means to be a minority language speaker - who, in addition, will also have many other identities as well, and which will be hierarchized according to personal schemata - in the $21^{\text {st }}$ century. 


\section{REFERENCES}

Abbou, Julie. 2011. Double gender marking in French: a linguistic practice of antisexism. Current Issues in Language Planning 12(1), 55-75.

Baxter, Judith. 2005. Feminist postructuralist discourse analysis. (Paper presented at BAAL/CUP seminar: Theoretical and Methodological Approaches to Gender and Language Study, 18-19 November 2005, The University of Birmingham, UK)

Broudic, Fañch. 2009. Parler breton au XXIe siècle. Le nouveau sondage de TMO-Régions. Brest: Emgleo Breiz.

Burnett, Heather and Bonami, Olivier. 2019. Linguistic prescription, ideological structure, and the actuation of linguistic changes: Grammatical gender in French parliamentary debates. Language in Society 48 (1), 65-93.

Council of Europe. 2010. Mosaic: The training kit for Euro-Mediterranean youth work. Strasbourg: Council of Europe Publishing.

Davies, Alan. 2003. The Native Speaker: Myth and Reality. Clevedon: Multilingual Matters.

Fishman, Pamela. 1978. Interaction: the work women do. Social Problems 25: 397-406.

García, Ofelía and Jo Ann Kleifgen. 2010. Educating emergent bilinguals: policies, programs, and practices for English language learners. New York: Teachers College Press.

Jouitteau, Mélanie. 2019. The Nativeness of Breton Speakers and Their Erasure. Studia Celtica Posnaniensia 4(1): 1-26.

Hawkey, James. 2018. Language Attitudes and Minority Rights The Case of Catalan in France. Cham: Palgrave Macmillan.

Hornsby, Michael. 2015. Revitalising Minority Languages: New Speakers of Breton, Yiddish and Lemko. Basingstoke: Palgrave Macmillan.

Hornsby, Michael. 2019. Positions and stances in the hierarchization of Breton speakerhood. Journal of Multilingual and Multicultural Development 40:5, 392-403

Irvine Judith and Gal, Susan. 2000. Language Ideology and Linguistic Differentiation. In: Kroskrity, Paul (ed.) Regimes of Language: Ideologies, Polities, and Identities, 35-83. Santa Fe, N.M.: School of American Research Press.

Kernalegenn, Tudi. 2006. Luttes écologistes dans le Finistère: Les chemins bretons de l'écologie 1967-1981. Fouesnant: Yoran Embanner.

Lakoff, Robin. 1975. Language and Women's Place. New York: Harper \& Row.

Lipovsky, Caroline. 2014. Gender-specification and occupational nouns: has linguistic change occurred in job advertisements since the French feminisation reforms? Gender and Language 8(3): 361-392.

Maltz, Daniel and Borker, Ruth. 1982. A cultural approach to male-female miscommunications. In John Gumperz (ed.) Language and Social Identity, 196-216. Cambridge: Cambridge University Press.

Ó hIfearnáin, Tadhg. 2011. Breton language maintenance and regeneration in regional education policy. In Norby, Catrin and John Hajek (eds.) Uniformity in language policy: Global perspectives, 93-108. Clevedon: Multilingual Matters.

Ó Murchadha, Noel and Ó hIfearnáin, Tadhg. 2018. Converging and diverging stances on target revival varieties in collateral languages: the ideologies of linguistic variation in Irish and Manx Gaelic. Journal of Multilingual and Multicultural Development 39(5): 458-469.

O'Rourke, Bernadette, Pujolar, Joan and Ramallo, Fernando. 2015. New Speakers of Minority Languages: The Challenging Opportunity - Foreword. International Journal for the Sociology of Language 231, 1-20. 
O'Rourke, Bernadette and Pujolar, Joan (eds). 2019. From New Speaker to Speaker: Outcomes, reflections and policy recommentations from COST Action IS1306 on New Speakers in a Multilingual Europe: Opportunities and Challenges. IAITH: Welsh Centre for Language Planning.

Pauwels, Anne. 1998. Women Changing Language. Harlow: Addison Wesley Longman.

Piller, Ingrid. 2001. Who, if anyone, is a native speaker? Anglistik. Mitteilungen des Verbandes Deutscher Anglisten, 12(2): 109-121.

Prewitt-Freilino, Jennifer L., Caswell, T. Andrew, and Laakso, Emmi K. 2012. The gendering of language: A comparison of gender equality in countries with gendered, natural gender and genderless languages. Sex Roles 66: 268-281.

Robiche, Lou. 2018. Pratiques Sociolinguistiques Francophones de Féminisation et de Dégenrement. (Francophone Sociolinguistic Practices of Feminization and Ungendering.) Paris: L’Harmattan.

Rampton, Ben. 1990. Displacing the 'native speaker': expertise, affiliation and inheritance. ELT Journal 44(2): 97-101.

Raynaudon-Kerzeho, Maiwenn, Le Bon, Anne and Le Corre, Didier. 2010. Que restera-t-il de la Bretagne dans 30 ans? Bretons 56: 51-57.

Smith-Christmas, Cassie, Ó Murchadha, Noel, Hornsby, Michael and Moriarty, Máiréad. 2018. New Speakers of Minority Languages Linguistic Ideologies and Practices. London: Palgrave Macmillan.

Sczesny, Sabine, Formanowicz, Magda, and Moser, Franziska. 2016. Can gender-fair language reduce gender stereotyping and discrimination? Frontiers in Psychology 7(25): 1-11.

Spender, Dale. 1980. Man Made Language. London: Routledge \& Kegan Paul.

Timsit, Annabelle. 2017. The Push to Make French Gender-Neutral: Can changing the structure of a language improve women's status in society? The Atlantic. 24 November 2017.https://www.theatlantic.com/international/archive/2017/11-/inclusive-writingfrance-feminism/545048/ (accessed 25.01.2020).

TMO Régions. 2007. Results reported in Broudic (2009).

Toussaint, Daria and Krazem, Mustapha. 2017. « Genre grammatical, genre sexuel et genre de discours: à propos du .e » (Grammatical gender, sexual gender and discourse gender: concerning .e). Cahiers de praxématique 69 | 2017. http://journals.openedition.org/praxematique/4658, accessed 20th March 2020.

Van Compernolle, Rémi A. 2009. What do women want? Linguistic equality and the feminization of job titles in contemporary France. Gender and Language 3(1): 33-52

Zimmerman, Don and West, Candace. 1975. Sex roles, interruptions and silences in conversation. In B. Thorne and N. Henley (eds) Language and Sex: Difference and dominance, 105-129. Rowley, MA: Newbury House. 